\title{
Insulin Assays in Two Cases of Spontaneous Hypoglycaemia Due to Retroperitoneal Mesothelioma
}

\author{
N. SAMAAN, ${ }^{*} \ddagger$ M.B., B.CH., M.R.C.P.ED. ; F. LAL, M.B., B.S.; RUSSELL FRASER,* M.D., F.R.C.P., D.P.M. ; \\ R. B. WELBOURN, $\dagger$ M.D., F.R.C.S.
}

Brit. med. F., 1965, 2, 195-198

The occurrence of hypoglycaemia in association with an extrapancreatic tumour is well recognized (Doege, 1930; Arkless, 1942 ; Hines, 1943 ; Scholz et al., 1957 ; Butterfield et al., 1960a, 1960b ; Steinke et al., 1962). The hypoglycaemia can be prevented by the surgical removal of the tumour, but the exact mechanism of the production of the hypoglycaemia is not understood. We report here two cases in which assays for insulin-like activity in the plasma and tissues may have helped to elucidate the mechanism.

\section{Case 1}

A spinster aged 67 had been well until August 1962, when she felt dizzy on rising one morning. Two days later she became dysphasic and had a fit with limb movements and incontinence. In a similar episode about two weeks later she was unconscious for 24 hours and a cerebrovascular accident was suspected. Recovery was rapid, and there was no residual weakness. During the next two months it was reported that her manner was infantile and that she was unrousable in the mornings until she was given sweet drinks. She was admitted to Hammersmith Hospital in November 1962 for investigation.

On examination she was lethargic and had obviously lost weight. The blood-pressure was $200 / 110 \mathrm{~mm}$. $\mathrm{Hg}$. The peripheral bloodvessels were atherosclerotic. A firm mobile mass, which could be pushed forward from the loin, was palpable just below the spleen, and the kidney could be felt below it. There was resonance on percussion over the mass. Investigations, including liver-function tests and urinary steroid measurements, showed nothing abnormal, except for the blood-glucose results (Table I). Radiological studies confirmed the presence of a large mass that was separate from the spleen and filled the left side of the abdomen.

* Department of Medicine, Postgraduate Medical School of London. t Department of Surgery, Postgraduate Medical School of London. \$ In receipt of an M.R.C. grant.
Laparotomy was performed on 18 Deceriber by Mr. R. H. Franklin. The liver, spleen, and pancreas were normal. The left kidney appeared normal, but was displaced downwards. A large encapsulated retroperitoneal tumour was found, with a big vein running across its surface. The left suprarenal gland appeared to be within the capsule of the tumour but was not invaded by it. The blood supply to the tumour seemed to be from the left suprarenal artery. Splenectomy was performed to give easier access to the tumour. The tumour weighed $1,136 \mathrm{~g}$. and measured 20 by 10 by $10 \mathrm{~cm}$. The external surface was irregular and lobulated.

The post-operative period was uneventful, except for an episode of haemorrhage from the wound. The blood-glucose levels were raised and there was slight glycosuria for about two weeks.

The patient was reassessed nine months after the operation and reported that she was feeling well. However, oral glucose-tolerance tests performed then and one month later showed fasting levels of 40 and $60 \mathrm{mg} . / 100 \mathrm{ml}$. respectively and levels of 25 and $35 \mathrm{mg} . / 100$ ml. two hours after the glucose had been administered. At this time she looked sleepy and started to stutter. There were no signs of metastases or of recurrence of the tumour. The glucose-tolerance test had reverted to normal 18 months after operation (Table I).

\section{Case 2}

A spinster aged 60 (height $5 \mathrm{ft} .1$ in. $(155 \mathrm{~cm}$.), weight $50 \mathrm{~kg}$.) was admitted to hospital when she was found to be unrousable. Later she regained consciousness spontaneously and reported two other similar episodes during the previous fortnight. On admission an unusual dysarthria and some impairment of memory were noticed, but there were no neurological abnormalities. She had mild hypertension $(200 / 110 \mathrm{~mm}$. $\mathrm{Hg}$ ). Examination of the abdomen showed a large, hard, non-tender mass in the left hypochondrium. There was resonance over it and it moved on respiration. During one of her attacks of unconsciousness the blood glucose was 36 $\mathrm{mg} . / 100 \mathrm{ml}$, and she recovered when glucose was given intravenously. In hospital it was found necessary to give her four-

TABLE I.-Glucose-tolerance Tests, including Serum-insulin Assays Before and After Operation

\begin{tabular}{|c|c|c|c|c|c|c|c|c|c|c|c|c|}
\hline & \multicolumn{2}{|c|}{ Conditions } & \multicolumn{7}{|c|}{ Blood glucose (mg./100 ml.) } & \multicolumn{3}{|c|}{ Serum Insulin-iike Activity in mu/l. (Typical/atypical) } \\
\hline & Meals & Fast & 0 & $\frac{1}{2}$ & 1 & $1 \frac{1}{2}$ & 2 & $2 \frac{1}{2}$ & $3 \mathrm{hr}$. & $I$ asting & $1 \mathrm{hr}$. & $2 \mathrm{hr}$. \\
\hline \multicolumn{13}{|l|}{ I. Case 1} \\
\hline $\begin{array}{l}\text { Pre-operative : } \\
21 / 11 / 62(-28 \text { days })\end{array}$ & Ordinary & $12 \mathrm{hr}$. & 25 & 93 & 117 & 92 & - & 25 & 28 & $\left.\begin{array}{l}13 \\
18\end{array}\right\} 16 / 403\left\{\begin{array}{l}385 \\
422\end{array}\right.$ & & \\
\hline $29 / 11 / 62(-20$ days $)$ & 3-hrly & 3-hrly & 60 & 220 & 205 & 125 & 70 & 80 & 58 & & & \\
\hline $7 / 12 / 62(-11$ days $)$ & . & & 35 & - & 150 & - & 115 & - & - & $\left.\begin{array}{l}11 \\
10\end{array}\right\} 11 / 187\left\{\begin{array}{l}184 \\
189\end{array}\right.$ & $43 / 128$ & $35 / 119$ \\
\hline $\begin{array}{lll}\text { Post-operative: } & & \\
17 \text { days } \\
9 \text { months } & . . & . .\end{array}$ & $\begin{array}{c}\text { Ordinary } \\
,\end{array}$ & $12 \mathrm{hr}$. & $\begin{array}{l}75 \\
40\end{array}$ & $\underline{75}$ & $\begin{array}{r}145 \\
70\end{array}$ & - & $\begin{array}{r}95 \\
25\end{array}$ & & & $105 / 80$ & $171 / 124$ & $17 / 128$ \\
\hline $\begin{array}{llll}10 & \prime & \because & \because \\
18 & \# & \end{array}$ & $"$ & $”$ & $\begin{array}{l}60 \\
70\end{array}$ & 二 & $\begin{array}{l}115 \\
110\end{array}$ & $\overline{-}$ & $\begin{array}{l}35 \\
65\end{array}$ & 60 & 60 & & & \\
\hline \multicolumn{13}{|l|}{$\begin{array}{l}\text { II. Case } 2 \\
\text { Pre }\end{array}$} \\
\hline $\begin{array}{l}\text { Pre-operative : } \\
\quad 21 / 3 / 64(-17 \text { days })\end{array}$ & & & & & & & & & & & & \\
\hline $25 / 3 / 64$ ( -13 days) & $\begin{array}{l}\text { Ordinary } \\
\text { 4hrly +i.v. } \\
\text { glucose for } \\
24 \mathrm{hr} .12 \mathrm{hr} \text {. } \\
\text { before }\end{array}$ & $\begin{array}{l}6 \mathrm{hr} . \\
4 \mathrm{hr} .\end{array}$ & $\begin{array}{l}26 \\
46\end{array}$ & $\begin{array}{l}133 \\
143\end{array}$ & $\begin{array}{l}164 \\
190\end{array}$ & $\overline{-}$ & $\begin{array}{l}73 \\
70\end{array}$ & 二 & $\begin{array}{l}29 \\
48\end{array}$ & $\begin{array}{r}35 / 245 \\
8 / 117\end{array}$ & $\begin{array}{l}62 / 183 \\
13 / 132\end{array}$ & $\begin{array}{r}105 / 240 \\
80 / 130\end{array}$ \\
\hline \multirow[t]{3}{*}{ 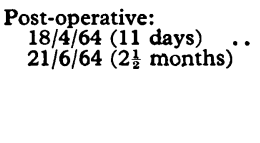 } & $\begin{array}{c}\text { Ordinary } \\
,\end{array}$ & $12 \mathrm{hr}$. & $\begin{array}{l}90 \\
70\end{array}$ & $\begin{array}{l}125 \\
150\end{array}$ & $\begin{array}{l}140 \\
115\end{array}$ & $\begin{array}{l}160 \\
110\end{array}$ & $\begin{array}{r}115 \\
65\end{array}$ & $\begin{array}{l}95 \\
80\end{array}$ & & $11 / 101$ & $77 / 98$ & $53 / 75$ \\
\hline & \multicolumn{12}{|c|}{ Ten Normal Subjects for Comparison (Mean \pm S.E.) (Samaan et al., 1962) } \\
\hline & Ordinary & $12 \mathrm{hr}$. & & & & & & & & $|47 \pm 14 \cdot 5 / 164 \pm 14 \cdot 5|$ & $188 \pm 50 / 165 \pm 20$ & $100 \pm 11 / 154 \pm 11$ \\
\hline
\end{tabular}


hourly meals of a mixed diet, by day and by night, to prevent hypoglycaemia.

An intravenous pyelogram showed downward displacement of the left kidney, and a barium-meal examination revealed displacement of the stomach to the right. Serum electrolytes and liver-function tests were normal. The urine showed a generalized increase of amino-acids but no excess of leucine. After a 12-hour fast the blood glucose was $25 \mathrm{mg} . / 100 \mathrm{ml}$. The results of the glucose-tolerance and other tests are shown in Tables I-III.

A diagnosis of retroperitoneal mesothelioma was made and laparotomy was performed on 7 April 1964 (R. B. W.). A huge retroperitoneal mass was found adherent to the left kidney and suprarenal and was removed en bloc with them. The tumour had to be dissected off the front of the pancreas, and, to avoid a fistula, the tail of the pancreas and the spleen were resected separately. There were no signs of metastases. During operation the patient received a constant intravenous drip. The tumour and adherent viscera measured 21 by $16 \mathrm{~cm}$. and weighed $3 \mathrm{~kg}$.

Recovery was rapid and the patient was discharged home after two weeks, free from a liability to hypoglycaemic attacks and with a normal 12-hour fasting blood sugar. Forty-five days after operation she was well and her glucose-tolerance test was found to be normal.

\section{Methods}

\section{Insulin Assay}

The insulin-like activity was assayed in the serum samples and tumour extracts by means of the epidtdymal fat pad of the rat, which was incubated in ${ }^{14} \mathrm{C}-1$ glucose, both in the presence and in the absence of insulin antiserum (Samaan et al., 1962a, $1962 \mathrm{~b}$ ). In this method the measurement of ${ }^{14} \mathrm{CO}_{2}$ production allows both "typical" and "atypical" insulin-like activity to be measured. The activity of the typical form is inhibited by the presence of the antibody, while that of the atypical form is not. The typical form is thus determined by the difference between the total and the atypical insulin-like activity levels.

\section{Collection and Preparation of Samples for Insulin Assay}

Case 1.-On 21 November 1962, after an overnight fast, serum samples were withdrawn. During the rest of the preoperative period she received, in addition to the routine ward diet, three-hourly glucose feeds. The glucose-tolerance tests on 29 November and 7 December were done during this regimen, and therefore after a fast of only three hours. An intravenous tolbutamide test was also done on 30 November, when she was on this regime. The post-operative glucose-tolerance test was done, after the standard 12-hour fast, on an ordinary ward diet. During the operation the patient received a continuous $5 \%$ glucose drip, and specimens for insulin assay were obtained simultaneously from the large vein draining the tumour and (as a control) from a gastric vein. A piece of the tumour was also taken for assay. All these samples were put in the deepfreeze immediately. The tumour tissue and the fasting serum samples of 21 November were extracted by the acid-ethanol method, as described by Scott and Fisher (1936) and modified by Grodsky and Forsham (1960).

Case 2.- Serum samples were taken during oral glucosetolerance tests and during intravenous tolbutamide and oral leucine tests before the operation. At this time the patient was having four-hourly meals to prevent hypoglycaemia. Two weeks after the operation the glucose-tolerance test was repeated and sera were assayed for both types of insulin-like activity. During the operation (while the patient was receiving glucose intravenously) blood was taken simultaneously from the main vein draining the tumour and from the aorta. Later, when the tumour, the tail of the pancreas, and the spleen had been removed, a specimen was taken from the splenic vein, which now drained the pancreas only. The tail of the pancreas was examined histologically. Equal pieces of the tumour and left kidney were extracted and assayed for insulin-like activity. and Hypoglycaemia-Samaan et al.

British
Medical Journal

\section{Results}

\section{Histology of the Tumours}

Histologically both tumours were similar. The microscopical sections showed cellular, vascular, fibrous tumours, composed of irregular narrow bands of collagen between masses of spindleshaped cells, showing whorling and regimentation. No mitoses were seen. The appearances suggested benign fibrous mesotheliomas. The left adrenal and the pancreatic islet-cell tissue in Case 2 were normal.

\section{Glucose-tolerance Tests (with Insulin Assay) (Table I)}

Blood Sugar.-The serial glucose-tolerance tests during the period of frequent carbohydrate feeds pre-operatively suggest a gradual lessening in the tendency to hypoglycaemia, as reflected by the 120-minute samples. Shortly after operation the glucosetolerance test in Case 1 was normal, while that in Case 2 was mildly diabetic, possibly as a result of the partial pancreatectomy. It is of interest that Case 1 later (at the ninth and tenth months) showed "functional" hypoglycaemia, owing perhaps to hyperplasia of the islets (Table I).

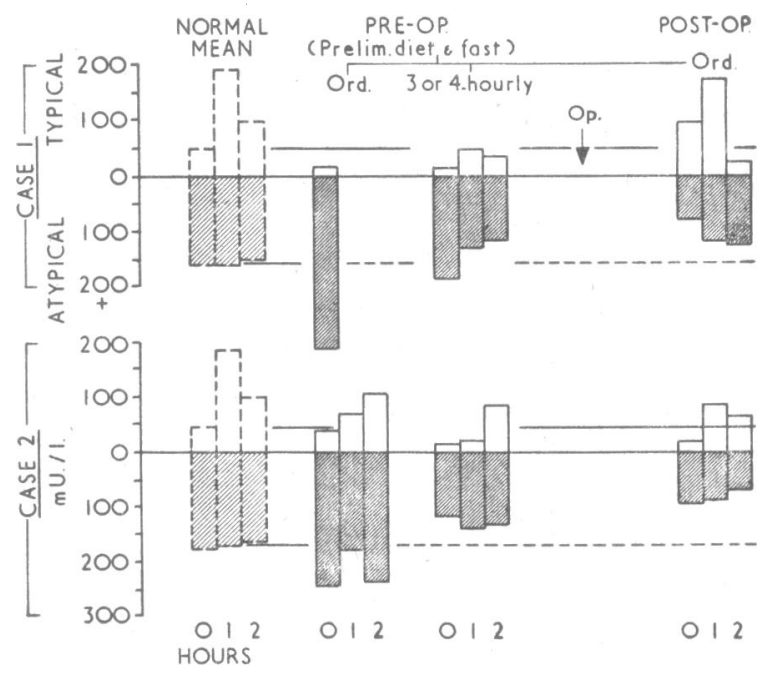

Serum insulin-like activity during glucose-tolerance tests in two patients before and after operative removal of mesotheliomas. Note preoperatively: (1) high levels of atypical insulin-like activity while on ordinary diet and (2) subnormal and delayed response in typical insulinlike activity after the glucose; and the restoration of these abnormalities within three weeks of the operation.

Insulin Assays (see Chart).-There are two abnormalities in the pre-operative tests, and these are most obvious during the tests done while the patients were taking ordinary meals. One is a tendency to high atypical insulin-like activity ; the other is little if any rise in the typical insulin-like activity in response to the oral glucose, in contrast to normal subjects, who show a fourfold or fivefold increase in typical insulin-like activity in the one-hour sample (from Samaan et al., 1962b). It is a little surprising to note, in both patients, that the frequent-eating regimen tended to restore not only the blood-glucose curve but also the serum insulin-like activity levels of the glucose-tolerance test towards normal. Possibly the tumour exerts its insulinreleasing effect mainly in the postprandial state. The high preoperative atypical insulin-like activity levels are also shown in the assays done on Case 2 during the tolbutamide and leucine tests (Table II). In both cases the post-operative tests show more normal glucose-tolerance tests-the initial one in Case I being normal and that in Case 2 being mildly diabetic.

\section{Pre-operative Tests to Stimulate Insulin Release (Table II)}

The standard tolbutamide test in Case 1 is difficult to interpret, since it started from a hypoglycaemia level; the 
patient showed no hypoglycaemic symptoms, nor any clear response of the blood glucose to tolbutamide. In Case 2 the initial value was less hypoglycaemic, and a slow, delayed, and subnormal response could just be discerned.

The effect of fasting alone for three hours was not measured, but since the blood glucose did not fall in response to leucine the results of the latter test may be taken to represent " fasting control" readings. The insulin assays during the tolbutamide test in Case 2 show that the typical insulin-like activity levels rose slowly, and provide confirmatory evidence of a subnormal and delayed response to tolbutamide. During the leucine test, although the blood glucose showed no response, the insulin assays hint at a possible minimal and slow response. These findings, together with the virtual absence of a response in typical insulin-like activity during the glucose-tolerance test, suggest that the patient's islets were very unresponsive to these stimuli. It may be that chronic stimulation by other means had exhausted their secretory reserve.

\section{Extracts and Operative Specimens: Insulin Assays and Glucose Levels (Table III)}

At operation the blood-glucose concentrations in the veins draining the tumours were similar to those from other sitesthe gastric vein in Case 1 (193 and $204 \mathrm{mg} . / 100 \mathrm{ml}$. respectively) and the aorta in Case 2 (255 and $255 \mathrm{mg} . / 100 \mathrm{ml}$. respectively).

The acid-ethanol extract of the fasting serum in Case 1 on 21 November 1962 yielded $175 \mathrm{mu}$. insulin/l. as typical and 85 $\mathrm{mu} . / 1$. as atypical. Thus the total extracted insulin-like activity . was $260 \mathrm{mu}$./1., which is only $62 \%$ of the level of $422 \mathrm{mu} . / 1$. assayed without extraction. While we have no explanation for the poor recovery from this sample, evidently most of the serum insulin-like activity in this subject was extractable like that of normal serum insulin-like activity. On 10 previous serum extractions (from other subjects) the recovery had usually been about $90 \%$. The insulin assays on the serum from the tumour veins yielded levels very comparable with those in either a perioheral vein (435 and $440 \mathrm{mu} . / 1$. total insulin in Case 1) or in the aorta (382 and $380 \mathrm{mu}$./1. total insulin in Case 2). Thus these assays gave no hint of secretion of insulin-like material by the tumours. Further, the extraction of the tumour tissue in Case 1 yielded $242 \mathrm{mu}$. of total insulin per $\mathrm{kg}$.- - that is, a concentration comparable with that found in the extracted peripheral venous serum. In Case 2 the tumour extract again gave a value slightly lower than that of unextracted aortic serum (225 and $380 \mathrm{mu} . / 1$. or $\mathrm{kg}$. respectively); and here the tumour insulin-like activity level was also found to be very similar to that extractable from the kidney tissue (225 and 260 $\mathrm{mu}$. total insulin-like activity per kg. respectively. Thus no more was extractable from the tumour tissue than from the venous serum or other tissue.

It should be noted that the amount of atypical insulin-like activity in the acid-ethanol extracts underestimates the amount of atypical insulin-like activity in the tissue and serum, as part of the atypical is changed to typical during the process of extraction (Samaan et al., 1963, and Table III). In addition, there is evidence in Case 2 that insulin was being secreted by the pancreas, for there was a high level of serum insulin-like activity, mainly typical, in the pancreatic vein $(825 \mathrm{mu}$. total insulin-like activity per litre compared with $380 \mathrm{mu}$./1. in the aorta).

\section{Discussion}

It has been pointed out that the syndrome of spontaneous hypoglycaemia associated with extrapancreatic "fibrosarcomalike tumours" may be cured by removal of the tumour, but that the mechanism of the hypoglycaemia has not yet been established. Excessive utilization of glucose by the tumour tissue has been suggested as a cause in such cases as well as in primary liver carcinoma (McFadzean and Yeung, 1956), and in adrenal cortical tumours (Williams et al., 1961). Our venous bloodglucose findings in these two patients are against this hypothesis. Butterfield et al. (1960a) reported similar findings.

The transient hyperglycaemia and glycosuria immediately after operation in Case 1 is similar to the transient hyperglycaemia which has also been reported after the removal of functioning pancreatic islet-cell tumours (Fraser et al., 1938; McMillan and Scheibe, 1951 ; de Peyster and Gilchrist, 1953).

Production of insulin by the tumour has been suggested by August and Hiatt (1958), who found insulin-like activity levels of $0.5 \mathrm{unit} / \mathrm{g}$. of tissue in the tumour extract, as measured by the rat diaphragm. However, they made no measurements on the serum. Steinke et al. (1962) did not find a high concentration of insulin in another case. Oleesky et al. (1962), using the immunochemical method of assay, found high insulin-like activity in the plasma in a case of retroperitoneal pelvic fibrosarcoma. They suggested that this tumour was probably secreting insulin, but that other factors could not be excluded. The results of insulin assays on the tumour extract were not mentioned. Our tumour assays do not support this theory, for they yielded values approximately equivalent to those found in

TABLE III.-Operative Specimens (Obtained During Steady Intravenous Glucose Infusion), Assayed for Insulin-like Activity

\begin{tabular}{|c|c|c|c|c|c|c|c|c|}
\hline \multirow{4}{*}{. } & \multicolumn{8}{|c|}{ Serum Insulin-like Activity in $\mathrm{mu} / \mathrm{l}$. or $\mathrm{kg}$. } \\
\hline & \multirow{3}{*}{ Aorta } & \multicolumn{3}{|c|}{ Unextracted Serum } & \multirow{3}{*}{$\begin{array}{c}\text { Peripheral } \\
\text { Vein }\end{array}$} & \multicolumn{3}{|c|}{ Acid-ethanol Extracts } \\
\hline & & \multirow{2}{*}{$\begin{array}{c}\text { Tumour } \\
\text { Vein }\end{array}$} & \multirow{2}{*}{$\begin{array}{c}\text { Pancreatic } \\
\text { (via Splenic) } \\
\text { Vein }\end{array}$} & \multirow{2}{*}{$\begin{array}{c}\text { Gastric } \\
\text { Vein }\end{array}$} & & \multirow{2}{*}{$\begin{array}{c}\text { Serum } \\
\text { (Peripheral } \\
\text { Venous) }\end{array}$} & \multicolumn{2}{|c|}{ Tisues } \\
\hline & & & & & & & Tumour & Kidney \\
\hline 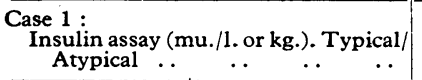 & $-1-$ & $35 / 400$ & $-1-$ & $-1-$ & $18 / 422$ & $85 / 175$ & $72 / 170$ & $-1-$ \\
\hline Total (blood glucose in $\mathrm{mg} . / 100 \mathrm{ml}$.) & & $435(193)$ & & (204) & 440 & 260 & 242 & \\
\hline $\begin{array}{l}\text { Case } 2 \text { : } \\
\text { Insulin assay (mu./1. or kg.). Typicall/ } \\
\quad \text { Atypical } \\
\end{array}$ & $222 / 158$ & $152 / 150$ & $682 / 143$ & $-1-$ & $-1-$ & $-1-$ & $30 / 195$ & $75 / 185$ \\
\hline Total (Blood glucose in mg./100 ml.) & $380(255)$ & $302(255)$ & 825 & & & & 225 & 260 \\
\hline
\end{tabular}
Serum Insulin-like Activity in mu./1. (Typical/atypical)

TABLE II.-Pre-operative Tolbutamide $(1 \mathrm{~g}$. i.v. $)$ and Leucine Tests $(0.2 \mathrm{g.} / \mathrm{kg}$. orally)

\begin{tabular}{|c|c|c|c|c|c|c|c|c|c|c|c|}
\hline \multicolumn{2}{|c|}{ Conditions } & \multicolumn{7}{|c|}{ Blood Glucose (mg./100 ml.) } & \multicolumn{3}{|c|}{ Serum Insulin-like Activity in mu./1. (Typical/atypical) } \\
\hline Meals ! & Fast & 0 & $\frac{1}{2}$ & 1 & $1 \frac{1}{2}$ & 2 & $2 \frac{1}{2}$ & $3 \mathrm{hr}$. & Fasting & $1 \mathrm{hr}$. & $2 \mathrm{hr}$. \\
\hline $\begin{array}{c}3 \text { hrly. } \\
4 \text { hrly. } \\
\text { " }\end{array}$ & $\begin{array}{c}3 \mathrm{hr} . \\
4 \mathrm{hr} . \\
\end{array}$ & $\begin{array}{l}40 \\
55 \\
50\end{array}$ & $\begin{array}{l}36 \\
38 \\
57\end{array}$ & $\begin{array}{l}32 \\
36 \\
60\end{array}$ & $\begin{array}{l}36 \\
40 \\
57\end{array}$ & $\begin{array}{l}38 \\
40 \\
62\end{array}$ & $\frac{40}{57}$ & 38 & $\begin{array}{l}5 / 235 \\
0 / 325\end{array}$ & $\begin{array}{r}9 / 260 \\
30 / 265\end{array}$ & $\begin{array}{r}120 / 230 \\
80 / 225\end{array}$ \\
\hline
\end{tabular}


the same weight of serum, and within the range of insulin-like activity we have found in normal tissues (Samaan et al., 1965). Further, even though the insulin production may not be reflected in the concentration of insulin extractable from the tumour tissue, the levels of insulin-like activity in the veins draining the tumours in our cases were not higher than those found in peripheral blood. In Case 2, where pancreatic venous blood was obtained, the typical insulin-like activity was much higher than that in the tumour vein.

The possibility remains that the tumours stimulate an increased production of endogenous insulin by the pancreas, as has been suggested by Berson and Yalow (1961). Sellman et al. (1959) found high levels of amino-acids in a sarcoma taken from a patient who exhibited hypoglycaemic attacks. Butterfield et al. (1960a, 1960b) suggested that it was unlikely that the peripheral tissues took up more glucose in response to these amino-acids, and that their hypoglycaemic effects in sensitive subjects might be due to a transient increase in plasma-insulin activity. Our findings suggest that there was excess serum insulin-like activity circulating pre-operatively, at least until the patients were receiving frequent glucose feeds. After this the serum insulin-like activity fell, possibly as a result of reduction, by the frequent feeds, of the tumours' capacity to stimulate the islets. During the pre-operative glucose-tolerance tests neither case showed the marked rise of serum typical insulin-like activity at 60 minutes which occurs in normal subjects (Table I). This suggests exhaustion of the islet secretion and reserve, perhaps by some chronic abnormal stimulus. The suggestion is supported by the slow return of the blood glucose from 60 to 120 minutes, and also by the subnormal or absent pre-operative response to tolbutamide.

The high levels of atypical insulin-like activity at the first assay (before the frequent feeds and when the spontaneous hypoglycaemia was occurring) suggest excessive previous production of insulin. This finding, together with evidence of defective insulin reserve, suggests that some excessive stimulus to normal insulin production may be the basis of the syndrome. Further support for this theory is provided by the attacks of hypoglycaemia found post-operatively in Case 1 . These were probably due to excessive secretion of insulin by hypertrophied islets. The histology of the pancreas is not helpful in these cases, since it is extremely difficult to differentiate between normal and hypertrophied islets. Moreover, the islet cells in the pancreas are not homogeneous in size and those in the tail may be smaller than those in the head.

\section{Summary}

Two cases of spontaneous hypoglycaemia relieved by operative removal of retroperitoneal mesotheliomas are reported.

Pre-operatively assays of serum insulin-like activity during glucose-tolerance tests showed a tendency to high atypical insulin-like activity, but little response of typical insulin-like activity to the glucose; nor was a response seen during a tolbutamide test. Post-operatively serum insulin-like activity levels during a glucose-tolerance test were normal.

Operative specimens showed no lowering of tumour-vein glucose, and serum insulin-like activity. levels in the tumour vein were the same as those in the aorta or gastric vein. The insulin-like activity was extractable from the tumour in slightly lesser concentrations than from serum or kidney, while the concentration found in pancreatic venous serum was over twice that from any other site.

These findings suggest that these tumours release a substance which stimulates insulin production by pancreatic islets.

We wish to express our indebtedness to Dr. J. G. Azzopardi for the histological reports, and to Dr. Ruth Haslam, of the Department of Chemical Pathology, for the glucose estimations.

\section{REFERENCES}

Arkless, H. A. (1942). Med. Bull. Veterans' Adm. (Wash.), 19, 225. August, J. T., and Hiatt, H. H. (1958). New Engl. F. Med., 258, 17. Butterfield, W. J. H., Kinder, C. H., and Mahler, R. F. (1960a). Lancet, 1,703 .

Whichelow, M. J., Wright, P. H., and Woolf, L. I. (1960b). Na:ure (Lond.), 188, 70

de Peyster, F. A., and Gilchrist, R. K. (1953). Arch. Surg., 67, 330.

Doege, K. W. (1930). Ann. Surg., 92, 955.

Fraser, R., MacLay, W. S., and Mann, S. A. (1938). Quart. F. Med., 7, 115 .

Grodsky, G. M., and Forsham, P. H. (1960). 7. clin. Invest., 39, 1070.

Grodsky, G. M., and Forsham, P. H. (1960). F. clin. Invest., 39,
Hines, R. E. (1943). Med. Bull. Veterans' Adm. (Wash.), 20, 102.

McFadzean, A. J. S., and Yeung, T. T. (1956). Arch. intern. Med., 98, 720.

McMillan, F. L., and Scheibe, J. R. (1951). Amer. F. Surg., 82, 759.

Oleesky, S., Bailey, I., Samols, E., and Bilkus, D. (1962). Lancet, 2, 378 Samaan, N. A., Dempster, W. J., Fraser, R., Please, N. W., and Stillman. D. (1962a). F. Endocr., 24, 263.

S.tillman, D., and Fraser, R. (1962b). Lancet, 2, 1287.

Fraser, R., and Dempster, W. J. (1963). Diabetes, 12, 339.

et al. (1965). To be published.

Scholz, D. A., Woolner, L. B., and Priestley, J. T. (1957). Ann. intern. Med., 46, 796 .

Scott, D. A., and Fisher, A. M. (1936). F. Pharmacol. exp. Ther., 58, 78. Sellman, J. C., Perkoff, G. T., Null, F. C., Kimmel, J. R., and Tyler, F. H. (1959). New Engl. F. Med., 260, 847 .

Steinke, J., Soeldner, J. S., and Renold, A. E. (1962). 7. clin. Invest., 41, 1403 .

Williams, R., Ke!lie, A. E., Wade, A. P., Williams, E. D., and Chalmers,
T. M. (1961). Quart. F. Med., 30, 269 .
The services of the Poisons Information Bureau at Leeds were made available to the public at the beginning of August 1961. A report of the work of the Bureau during the first 16 months was made at the Third International Meeting in Forensic Medicine and Toxicology held in April 1963. Since that time the work of the Bureau has gradually increased. In this paper a report of three full years' working, to 31 July 1964, is given describing the work in all its aspects.

* Surgeon, United Leeds Hospitals.

+ Group Pharmacist, United Leeds Hospitals.

\section{Number of Calls Received}

In the three years a total of 1,492 calls have been made to the Bureau. In Table I an analysis of the calls received month by month is given. It will be noticed that in the first seven months after the opening of the Bureau only 20 inquiries a month were made. Since that time, however, about 45 calls on average have been received each month. On 1 September 1963 the bureaux established by the Ministry of Health at London, Cardiff, Edinburgh, and Belfast were opened. It might have been expected that our work would have been con- 